\title{
Nationalism and Political Identity
}

Sandra F. Joireman

Continuum, London \& New York, 2003, viii $+164 p p$.

ISBN: 0826465919.

Contemporary Political Theory (2005) 4, 332-334. doi:10.1057/palgrave.cpt.9300195

Nationalism and Political Identity is a welcome addition to International Relations texts and articulates the international importance of ethnicity. In this highly accessible and user-friendly introduction, Joireman provides a compelling account of ethnic and nationalist conflicts and ways of understanding and seeking to overcome them. In doing so she considers the wider political implications of ethnicity and incorporates this into the field of International Relations. In speaking of 'political identity', Joireman moves beyond the nationalist/ethnic divide and draws parallels between the two that alert us to the cross disciplinary potential for future research.

The book presents a comprehensive summary of theoretical debates in the field - running through the primordialist, instrumentalist and constructivist accounts of ethnicity — before offering four detailed case studies that highlight complexities and prompt discussion. Each chapter concludes with a set of questions inviting the reader to consider the issues in greater depth. The book is well sign-posted and meticulous in defining and explaining key terms and concepts. As such it will be invaluable as a text book for lay readers, A-level or first-year students of politics or sociology. The book will also be a useful reference point for a wider audience, but a paucity of references and a tendency for narrative drive render it of limited interest to an academic readership.

The central premise of the book is that nationalism is a politicized form of ethnicity. This assertion allows Joireman to draw on the diverging literatures and arrive at conclusions which amalgamate both areas of study. This approach throws up several insights and underscores the international significance of ethnic conflict. The application of work on in-groups and out-groups to the study of nationalism seems particularly apposite. A problematic aspect of this hypothesis, however, is that ethnicity and nationalism are conflated and the terms are used interchangeably. 'Nationalism', as Joireman puts it, 'is ethnic identification that has in some way become politicized' (p. 146).

The nationalism in question here is what Billig (in Banal Nationalism, 1995) refers to as 'hot', violent or exclusionary nationalism. Whilst the book does contain some reference to - and discussion of - Billig's notion of 'banal nationalism', the processes and practices that go into the everyday (re)production of national identity are in large part obscured. Furthermore, 
in defining nationalism as 'politicized ethnicity' (p. 12), Joireman effectively negates the nationalist struggles of diverse nations such as India, and overlooks the 'banal nationalism' of multi-ethnic countries like the United States of America. Joireman is correct to note the increasingly international dimensions of identity formation and conflict resolution, yet fails to deal adequately with the correlate processes of migration, multi-culturalism and globalization.

An offshoot of this is that the ethnic identity of majority populations is hardly mentioned. An unsettling conclusion that could be drawn here is that nations are based upon fairly homogenous ethnic groups - or should be if ethnic violence is to be avoided. While such a finding runs contrary to the ethos of the book, it is inescapable when religious groups, castes, linguistic clusters or political movements are categorized as nations when they mobilize politically.

Joireman could profitably have spent more time debating the contentious contours of nationalism and ethnicity. As it stands, the conflation of the two identities means Joireman is compelled to differentiate between 'ethnic-nations' and 'states'. 'States' surface occasionally, particularly in Chapter 1, but are not defined. The 'state' thus seems to operate as a black box whose workings are impenetrable to analysis. In fact, as the case studies amply illustrate, states are key players in the mobilization or suppression of ethnic identities. It is unhelpful, therefore, for the state to be presented as effectively neutral in the face of ethnic conflict and competition elsewhere. We are told that emotional and political ties 'lead people to take up arms against the state' (p. 10) — but not what they are seeking to attain, or how the state is formed.

The picture we are left with is of benign ethnic identities subsisting happily within states until they are politicized by deeply held feelings, instrumentalist leaders or changing political circumstances. At this point ethnic groups transmute into national ones. Joireman asks the reader to consider which theoretical approach best fits the case in hand, but we are left with as many questions as answers. More attention could have been paid to the microprocesses by which ethnic identities are endowed with meaning, accorded political significance and made to 'stick'. Joireman fittingly spends time debunking the notion that we are ineluctably wedded to a single identity and takes pains to highlight the multiplicity of identity choices open to us. She notes that 'we each decide for ourselves which identities are most important'. Not only does this obscure the fact that groups are differently placed (and some have more options than others), but this aspect of agency is dormant in analysis of the case studies.

The book is admirable in its attempt to promote debate rather than provide answers and, perhaps, this endeavour to avoid didacticism results in some of the confusion highlighted above. The examples offered certainly provide an array of cases from the spectrum of ethnic and nationalist conflict, and chart instances of long-standing ethnic rivalry as well as the Eritrean example in 
which a political identity emerged out of the colonial encounter with Italy. To my mind, these contrasts and ambiguities over what we mean by nationalism and ethnicity - and when they can be classified as such - could have been brought to the fore. In sum, Joireman has provided an informative and accessible introduction to the fields of ethnicity and nationalism, which recaptures the important role of sub-national mobilization within the study of International Relations. It is important to bear in mind the more mundane and everyday aspects of ethnicity and nationalism, but this book is a good introduction to the field.

Hugo Gorringe

University of Edinburgh, UK.

\author{
The Party's Over: Blueprint for a Very English Revolution \\ Keith Sutherland \\ Imprint Academic, Exeter, 2004, 202pp. \\ ISBN: $0907845908 / 0907845517$.
}

Contemporary Political Theory (2005) 4, 334-336. doi:10.1057/palgrave.cpt.9300196

Incisive critiques of democracy began with Plato and Aristotle and burgeoned in the last three centuries when representative democracy became a possibility or, increasingly, a reality. Some critiques are based on normative considerations: for example, it is irrational to have the ignorant masses taking decisions rather than the wise elite (Plato and James Mill). The 20th-century evaluations focused mainly on practical considerations, on the ways in which democracy had proved defective when put into practice. Keith Sutherland follows the practical criticism tradition, arguing not against democracy itself, but against the instantiation of democracy as a system which gives a monopoly of power to party leaders, and against the corrupting effect of partisanship on deliberation and informed choice.

An initial impression might be that Sutherland is against democracy in principle, but in fact his aim is to lance 'the boil of the all-consuming myth of electoral democracy' (p. 164). Electoral systems beget parties. Parties, far from being Burkean groupings of representatives with a shared view of the country's wellbeing, are organizations focused exclusively on gaining or maintaining power.

Sutherland proposes to abolish electoral democracy and political parties in his 'blueprint for a very English revolution'. Although the proposals are couched in terms of the British system ('the Crown in Parliament' etc.), his 